Article

\title{
Olfactometer Responses of Convergent Lady Beetles Hippodamia convergens (Coleoptera: Coccinellidae) to Odor Cues from Aphid-Infested Cotton Plants Treated with Plant-Associated Fungi
}

\author{
Janaina Camara Siqueira da Cunha ${ }^{1, *(\mathbb{D})}$, Morgan H. Swoboda ${ }^{1,2} \mathbb{D}$ and Gregory A. Sword ${ }^{1, *}$ \\ 1 Department of Entomology, Texas A\&M University, College Station, TX 77843, USA; mhs338@cornell.edu \\ 2 Department of Entomology, Cornell University, Ithaca, NY 14850, USA \\ * Correspondence: janaina.cunha@tamu.edu (J.C.S.d.C.); gasword@tamu.edu (G.A.S.)
}

Citation: Camara Siqueira da Cunha, J.; Swoboda, M.H.; Sword, G.A.

Olfactometer Responses of

Convergent Lady Beetles Hippodamia convergens (Coleoptera:

Coccinellidae) to Odor Cues from

Aphid-Infested Cotton Plants Treated with Plant-Associated Fungi. Insects 2022, 13, 157. https://doi.org/ $10.3390 /$ insects 13020157

Academic Editors: Kerry M. Oliver and Julia Ferrari

Received: 20 October 2021

Accepted: 25 January 2022

Published: 31 January 2022

Publisher's Note: MDPI stays neutral with regard to jurisdictional claims in published maps and institutional affiliations.

Copyright: (C) 2022 by the authors. Licensee MDPI, Basel, Switzerland. This article is an open access article distributed under the terms and conditions of the Creative Commons Attribution (CC BY) license (https:// creativecommons.org/licenses/by/ $4.0 /)$.
Simple Summary: The cotton aphid Aphis gossypii is a serious agricultural pest. Microbes associated with plants can affect the behavior and performance of insect herbivores and their natural enemies. Phialemonium inflatum and Chaetomium globosum fungi can reduce cotton aphid reproduction when applied as a seed treatment to cotton. We evaluated whether these fungi might affect the interaction between cotton aphids and a natural enemy, the convergent lady beetle Hippodamia convergens. We used dual-choice olfactometer experiments to assess lady beetle behavioral responses to cues from fungal-treated cotton plants in the presence or absence of aphid infestations. In the absence of fungal treatments, males preferred odors from aphid-infested relative to non-infested plants, and females spent more time associated with olfactory stimuli from aphid-infested versus non-infested plants. When cues from fungal-treated plants infested with aphids were assessed, there were no differences in lady beetle responses. The only fungal treatment-related effects involved plants without aphids. In the absence of aphids, males responded slower to P. inflatum-treated plants compared to control, and females preferred $P$. inflatum-treated plants. Treating cotton with these potentially beneficial fungi had minor effects on lady beetle behavioral responses and would not be expected to disrupt this predator-prey-plant interaction as part of an integrated pest management strategy.

Abstract: Microbes have the potential to affect multitrophic plant-insect-predator interactions. We examined whether cotton plants treated with potentially beneficial fungi affect interactions between cotton aphids Aphis gossypii and predatory lady beetles Hippodamia convergens. We used Y-tube olfactometer assays to test lady beetle behavioral responses to stimuli emitted by aphid-infested and non-infested cotton plants grown from seeds treated with either Phialemonium inflatum (TAMU490) or Chaetomium globosum (TAMU520) versus untreated control plants. We tested a total of 960 lady beetles ( 480 males and 480 females) that had been deprived of food for approximately $24 \mathrm{~h}$. In the absence of any fungal treatments, males preferred stimuli from aphid-infested plants, and females spent more time associated with stimuli from aphid-infested versus non-infested plants. When fungal treatments were added, we observed that lady beetles preferred non-aphid-infested P. inflatum plants, and males responded slower to plants treated with P. inflatum in the absence of aphids. We found some evidence to suggest that lady beetle behavioral responses to plants might vary according to the fungal treatment but not strongly impact their use as part of an insect pest management strategy.

Keywords: olfactory preference; multitrophic interactions; microorganisms; predator

\section{Introduction}

A phytobiome is the association between plants, the environment, and micro- and macroscopic organisms influencing plant growth, health, and productivity [1,2]. A wide variety of studies have shown that plant-associated microbes, including fungi, can enhance 
plant resistance or tolerance against biotic and abiotic stressors such as insect herbivores, pathogens, plant-parasitic nematodes, drought, and heat [3-13].

Many plant-associated microbes can induce plant host defenses through Systemic Acquired Resistance (SAR) and Induced Systemic Resistance (ISR) $[4,14,15]$. For example, a laboratory study inoculating maize seeds with an endophytic fungus showed the fungus promoted plant growth, altered the expression of defensive genes belonging to the jasmonic acid (JA) pathway, and suppressed herbivore larvae growth rate [16]. Moreover, microbes can affect the production of various chemicals by the plant, including volatile organic compounds (VOCs), thereby modifying plant responses [17-19]. These altered volatile profiles can affect herbivore host-selection behavior [20-22]. Consequently, these changes in volatile chemical bouquets could also affect the attraction of natural enemies, such as predators and parasitoids [23,24].

The cotton aphid, Aphis gossypii Glover (Hemiptera: Aphididae), is a well-known pest that can cause severe economic losses in cotton fields $[25,26]$. Some plant-associated fungi have been shown to negatively affect cotton aphid reproduction and alter feeding behavior $[5,8,27,28]$. Diverse species in the family Coccinellidae (Coleoptera) are voracious aphid predators [29] and agriculturally valuable biological control agents [30,31]. One example is the generalist predator Hippodamia convergens (Guérin-Méneville), commonly known as the convergent lady beetle. This aphidophagous species is found broadly across the Western Hemisphere [32]. Due to their predaceous habit and distribution among crops attacked by aphids, this species is often considered an important part of many agroecosystems as an essential biological control agent [33]. However, most studies assessing the effects of plant-associated fungi on lady beetles have only been limited to grasses [34-36] despite its presence in many other crops, including cotton [37,38].

In order to better manage insect pests, we may be able to manipulate a plant's phytobiome to increase the efficiency of natural enemies [39,40]. Knowledge about pests and their natural enemies is crucial for the development and implementation of sustainable pest management strategies in cotton [39]. Cotton plants treated with some beneficial plantassociated fungi have previously been shown to negatively affect aphid reproduction $[5,8]$. However, whether these plant-associated fungi might also affect the behavior of an aphid predator in a multitrophic interaction has not been investigated to date. As such, the goal of this study was to investigate the effects of plant-associated fungi applied to cotton plants on convergent lady beetle behavior.

\section{Materials and Methods}

\subsection{Fungal Treatment of Cotton Seeds}

Chemically untreated Gossypium hirsutum seeds of the non-transgenic variety LA122 were obtained from All-Tex Seed Inc., Levelland, TX, USA. The fungal strains used were Phialemonium inflatum (TAMU490) and Chaetomium globosum (TAMU520), which were first isolated as endophytes from surface-sterilized cultivated cotton as part of a field survey in Texas, USA [41]. The fungal inoculum for all trials was cultured in $100 \times 15 \mathrm{~mm}$ Petri dishes on potato dextrose agar (PDA) in the dark at $25{ }^{\circ} \mathrm{C}$. Spore suspensions of each fungus were made by adding $2 \mathrm{~mL}$ of $0.1 \%$ Triton X-100 solution to the fungal conidia plates, scraping them with a sterile metal spatula, filtering through autoclaved $0.25 \mathrm{~mm}$ sieves into a sterile beaker, and placing them in $50 \mathrm{~mL}$ centrifuge tubes [9]. The suspensions were mixed on a vortex and then centrifuged for $10 \mathrm{~min}$ in a Cole-Parmer fixed-speed centrifuge at $3000 \mathrm{rpm}$. Excess water was removed by pouring out the supernatant. We used a Neubauer hemocytometer (Thomas Scientific, Philadelphia, PA, USA) to quantify the spores' concentration. Final treatment concentrations were diluted with sterile water to reach $1 \times 10^{8}$ spores $/ \mathrm{mL}$ [9].

Cotton seeds were surface sterilized by immersion in $3 \%$ sodium hypochlorite $(\mathrm{NaOCl})$ for $3 \mathrm{~min}$, and 70\% ethanol for $2 \mathrm{~min}$, followed by three rinses in sterile water [42]. Before applying the fungal treatment, surface-sterilized seeds were dried on sterile paper towels for $30 \mathrm{~min}$. The seeds were inoculated with spore suspensions (approximately 200 seeds/ $1 \mathrm{~mL}$ ) 
plus $1 \mathrm{~mL}$ of a $2 \%$ methylcellulose sticker to bind the spores to the seeds. We treated the control seeds with $1 \mathrm{~mL}$ of $2 \%$ methylcellulose only. Treated seeds were dried for at least three hours after inoculation before planting. Five treated seeds per treatment were plated in Petri dishes containing PDA to confirm inoculation with viable fungi [9]. Three seeds per treatment were planted in $515 \mathrm{~mL}$ pots with unsterilized MetroMix 900 soil (Sun Gro Horticulture, Agawam, MA, USA). For the duration of the experiment, all plants were grown in a greenhouse at approx. $25{ }^{\circ} \mathrm{C}$ with natural photoperiod. Pots were randomized and watered as needed at least once a week.

\subsection{Insect Rearing and Experimental Design}

We assessed lady beetle behavioral responses to olfactory stimuli emitted by cotton plants grown in the USA from seeds treated with plant-associated fungi using a dual-choice Y-tube olfactometer (described below). To prepare aphid-infested plants for the behavioral assays, third true-leaf plants from each fungus and untreated control treatments were initially infested with 10 aphids per plant two weeks before the trials with cotton aphids from a colony maintained in the Sword Lab at Texas A\&M University. The colony was maintained on cotton plants in the greenhouse at $25^{\circ} \mathrm{C}$ with natural photoperiod ranging from 12L:12D to 14L:10D, with new non-treated plants being placed in the cages weekly. A total of 18 infested plants per treatment were maintained inside multiple insect mesh cages and housed in a greenhouse under the conditions mentioned above. Plants from all three treatment groups that were not infested with cotton aphids were maintained in the same environmental conditions as the infested plants. Although previous studies have shown a decrease in aphid reproduction on plants grown in the USA from fungal-treated seeds $[5,8,11]$, aphid populations on treated plants nevertheless increase over time. In these experiments, aphid populations on treated plants had recovered by two weeks after infestation such that all plants had similar aphid infestation levels.

Convergent lady beetle adults, Hippodamia convergens, were obtained from ARBICO Organics $^{\circledR}$ (Oro Valley, AZ, USA) originally collected from overwintering aggregations in California, USA $[43,44]$. Prior to use in the trials, the beetles were sexed and maintained in reproductive diapause in $44 \mathrm{~mL}$ plastic cups at $3{ }^{\circ} \mathrm{C}[45,46]$. For use in experiments, ten individuals per cup were arranged randomly on trays inside an incubator at $25^{\circ} \mathrm{C}$, 50-60\% RH, and 16:8 L:D photoperiod [44]. The lady beetles were fed once for $24 \mathrm{~h}$ with approx. 30 cotton aphids per adult from the aphid colony and a moistened cotton wick inside the cups in the incubator before starting the pre-experiment starvation period. Convergent lady beetles were also field collected from sorghum plants at the Texas A\&M AgriLife Research Farm in Burleson County, TX and maintained under the same conditions. All adult lady beetles were starved $\sim 24 \mathrm{~h}$ before the behavior assays [47-49].

Because the lady beetles came from two different source populations as described above, we conducted a control experiment to test for differences between the commercial and wild-caught individuals in their preference for stimuli from cotton plants with and without aphids in the absence of any fungal treatments. No difference was observed (see Results). We then tested for the effects of fungal cotton seed treatments on lady beetle behavior by conducting choice tests between stimuli from one untreated control versus one fungal-treated plant (TAMU490 or TAMU 520). We conducted this comparison between untreated and fungal-treated plants using plants that were either aphid-free or aphidinfested in two separate series of trials. We used a total of 960 adults, 120 for the initial comparison between commercial and wild-caught populations (60 males and 60 females per population), 120 for the untreated control aphid-infested and non-infested plants, 240 in each comparison of fungal-treated plants aphid-infested and non-infested plants, and 240 in each of the two separate comparisons between fungal-treated and untreated plants in either the presence or absence of aphids. Plant positions (left or right) in the olfactometer were alternated after every five individuals, and new plants were exchanged after every 30 individuals. Each adult was tested only once and discarded after the experiment. 


\subsection{Y-Tube Olfactometer}

The olfactometer consisted of a Y-shaped glass tube with a trunk measuring $15.2 \mathrm{~cm}$ and each arm $12.7 \mathrm{~cm}$ (Figure 1). Two 2 L glass jars were attached to the outside as chambers for each plant. The jars' lid was modified with an opening through which the plant stem was placed. The space between the lid and stem was then sealed with non-toxic clay to avoid air escaping, thereby isolating the stem and leaves within the jar. A filter was connected in series to a water bubbler to humidify the incoming air pulled from a DOA series oilless diaphragm vacuum pump (Thomas Scientific). The filters were attached to silicone tubes, and the flow was measured with an Acrylic Flowmeter (Cole-Parmer Scientific Experts, Illinois, USA). The olfactometer was positioned horizontally on a countertop [50,51] inside a dark room. The light source came from a flexible LED strip light equidistantly placed to provide uniform light to both arms of the olfactometer. Carbon filtered humidified air was pumped in at $\sim 2.0 \mathrm{~L} \mathrm{~min}^{-1}$, and a single adult convergent lady beetle was introduced at the base of the Y-tube olfactometer. The air was monitored, checking the flowmeter during the whole observation to ensure it was not escaping and interfering with the assay.

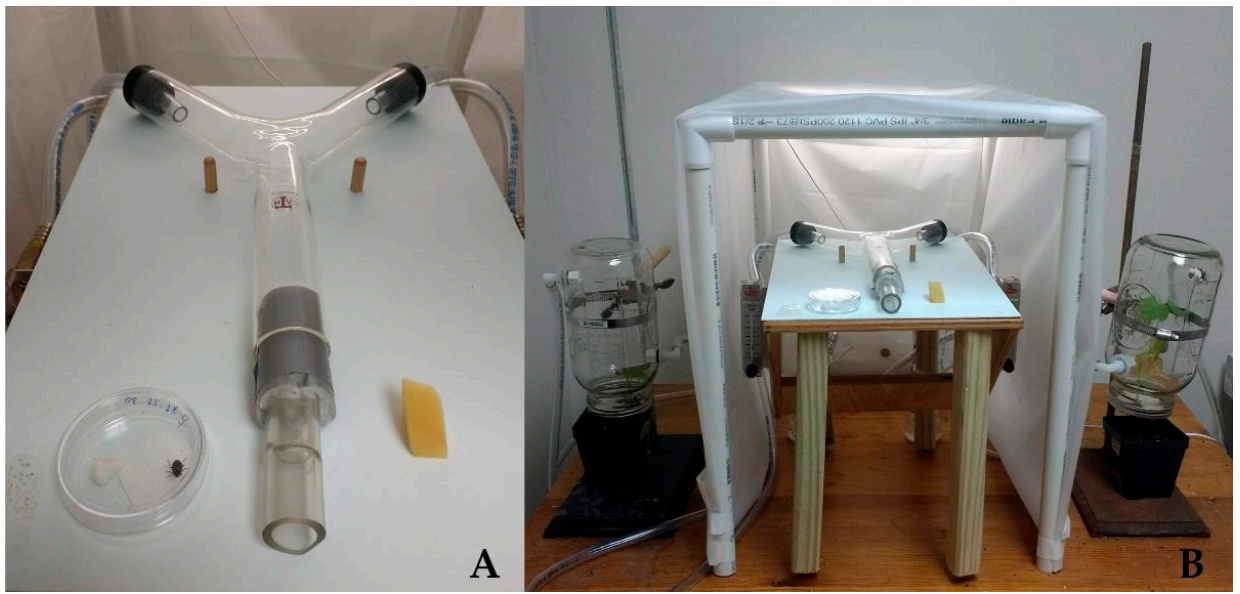

Figure 1. Y-shaped glass tube with the acclimation chamber (A) and the entire olfactometer setup showing the plant chambers (B).

After five individuals were tested, we changed the Y-tube, the jars, and the treatment sides to avoid positional bias [52,53]. Jars were cleaned with fragrance-free soap, rinsed with water, and dried in an oven at $80{ }^{\circ} \mathrm{C}$ to sterilize and avoid residuals from the previous treatment [50]. Adult lady beetles were gently introduced into the release chamber with a \#2/0 Daler-Rowney paintbrush and allowed to acclimate for five minutes [50]. Consistent with previous olfactometer studies, the insect had $10 \mathrm{~min}$ to choose between the different stimuli [54-56]. We recorded the insect responses as a choice when they entered at least halfway up into one arm of the Y-tube and remained there for at least $20 \mathrm{~s}$ [51]. Within the $10 \mathrm{~min}$, we recorded the first choice, latency (time to make a choice), and residence time (time spent in an arm) [52,53]. If an individual did not choose within five minutes, it was recorded as "no choice" and excluded from the statistical analysis [57-59].

\subsection{Statistical Analysis}

We recorded the number of responding lady beetles (females and males) and expressed it as a proportion calculated as the number of individuals that chose a given treatment divided by the total number of individuals that selected either the treatment or control stimulus. The proportions of responding individuals yield a value between 0 and $1[9,60]$. We analyzed the proportions using Pearson's chi-squared test [61], testing the null hypothesis that $H$. convergens showed no preference for either arm, and the expected proportion was equal to $0.5[59,62]$. The latency and residence time data were transformed to satisfy the assumptions of normality using $\log (x+1)$ [63] and compared the means of each sex between treatments using Welch's two-sample $t$-test $[52,61,64]$. We used ANOVA to analyze 
if there was a difference between wild and commercial lady beetle responses. All analyses were done using $\mathrm{R}$ version 3.6.3 [61] with a 5\% significance level $(\alpha=0.05)$, and we used the ggplot2 package for graphs [65].

\section{Results}

\subsection{Wild and Commercial H. convergens Responses}

We found no differences in the behavior of wild versus commercially obtained lady beetles in response to aphid-infested and non-infested cotton plants in the absence of any fungal treatments. The first-choice responses from $H$. convergens wild and commercial females and males were not significantly different $\left(F_{1,91}=0.0141, p=0.9132\right)$. Moreover, there was no significant difference in either latency $\left(F_{3,89}=2.01, p=0.1182\right)$ or residence time $\left(F_{4,88}=0.3669, p=0.777\right)$ between wild and commercial individuals of both sexes. Since we did not find a significant difference between responses of wild and commercial $H$. convergens, their responses were not incorporated in the analysis.

\subsection{First Choice}

In the Y-tube olfactometer, $H$. convergens females did not show a significant preference for stimuli emitted by untreated cotton plants that were either infested or not infested with aphids. However, when the females were exposed to stimuli from P. inflatum fungal-treated plants with or without aphids, they significantly preferred stimuli from non-infested plants more often. There were no significant differences in the first choices between stimuli from plants that had been treated with either fungus versus untreated control plants, regardless of whether the plants were infested or not with aphids (Table 1, Figure 2). In contrast, $H$. convergens males did show a significant preference for aphid-infested plants over non-infested plants in the absence of any fungal treatments, but the fungal treatments did not affect their responses regardless of whether aphids were present or absent (Table 1, Figure 2).

Table 1. Statistical analyses of the first choice, latency, and residence time in seconds for female and male Hippodamia convergens. Tests were conducted in a Y-tube olfactometer providing individuals with a choice between stimuli emitted by fungal-treated or untreated cotton plants in the presence or absence of aphids. Sample sizes for each comparison were $\mathrm{N}=60$ for each sex. ${ }^{*} p \leq 0.05$.

\begin{tabular}{|c|c|c|c|c|c|c|c|c|c|c|c|c|c|c|}
\hline & \multicolumn{4}{|c|}{$\begin{array}{c}\text { Pearson's Chi-Squared Test } \\
\text { First Choice }\end{array}$} & \multicolumn{4}{|c|}{$\begin{array}{c}\text { Welch's Two-Sample } \\
t \text {-Test } \\
\text { Latency Time }\end{array}$} & \multicolumn{4}{|c|}{$\begin{array}{c}\text { Welch's Two-Sample } \\
t \text {-Test } \\
\text { Residence Time }\end{array}$} & \multicolumn{2}{|c|}{$\begin{array}{l}\text { Nonresponding } \\
\text { Individuals }\end{array}$} \\
\hline & \multicolumn{2}{|c|}{$\sigma^{7}$} & \multicolumn{2}{|c|}{ q } & \multicolumn{2}{|c|}{$0^{x}$} & \multicolumn{2}{|c|}{ q } & \multicolumn{2}{|c|}{$\sigma^{7}$} & \multicolumn{2}{|c|}{ q } & \multirow{2}{*}{$0^{7}$} & \multirow{2}{*}{ q } \\
\hline & $x^{2}$ & $p$ & $x^{2}$ & $p$ & $t$ & $p$ & $t$ & $p$ & $t$ & $p$ & $t$ & $p$ & & \\
\hline \multicolumn{15}{|c|}{ Fungus absent } \\
\hline $\begin{array}{l}\text { Aphids vs. } \\
\text { no aphids }\end{array}$ & 4.57 & $0.03 *$ & 1.77 & 0.18 & 1.18 & 0.26 & 1.44 & 0.17 & -1.98 & 0.07 & 2.13 & $\begin{array}{l}0.05 \\
*\end{array}$ & 23 & 24 \\
\hline \multicolumn{15}{|c|}{ C. globosum } \\
\hline $\begin{array}{l}\text { Aphids vs. } \\
\text { no aphids }\end{array}$ & 2.08 & 0.15 & 0 & 1 & 0.78 & 0.45 & -0.45 & 0.66 & 1.04 & 0.32 & -0.23 & 0.82 & 21 & 16 \\
\hline \multicolumn{15}{|c|}{ P. inflatum } \\
\hline $\begin{array}{l}\text { Aphids vs. } \\
\text { no aphids }\end{array}$ & 3.27 & 0.07 & 4.92 & $0.02 *$ & 0.74 & 0.48 & -1.44 & 0.17 & -0.03 & 0.98 & -0.39 & 0.69 & 23 & 8 \\
\hline \multicolumn{15}{|c|}{ Fungus present/Aphids absent } \\
\hline $\begin{array}{l}\text { C. globosum } \\
\text { vs. control }\end{array}$ & 1.12 & 0.29 & 0.23 & 0.63 & 1.7 & 0.1 & -1.38 & 0.19 & -0.6 & 0.55 & 1.14 & 0.27 & 28 & 21 \\
\hline
\end{tabular}


Table 1. Cont.

\begin{tabular}{|c|c|c|c|c|c|c|c|c|c|c|c|c|c|c|}
\hline & \multicolumn{4}{|c|}{$\begin{array}{c}\text { Pearson's Chi-Squared Test } \\
\text { First Choice }\end{array}$} & \multicolumn{4}{|c|}{$\begin{array}{c}\text { Welch's Two-Sample } \\
t \text {-Test } \\
\text { Latency Time }\end{array}$} & \multicolumn{4}{|c|}{$\begin{array}{c}\text { Welch's Two-Sample } \\
t \text {-Test } \\
\text { Residence Time }\end{array}$} & \multicolumn{2}{|c|}{$\begin{array}{l}\text { Nonresponding } \\
\text { Individuals }\end{array}$} \\
\hline & \multicolumn{2}{|c|}{$0^{7}$} & \multicolumn{2}{|c|}{ ㅇ } & \multicolumn{2}{|c|}{$\sigma^{x}$} & \multicolumn{2}{|c|}{ q } & \multicolumn{2}{|c|}{$\sigma^{7}$} & \multicolumn{2}{|c|}{ q } & \multirow{2}{*}{$0^{7}$} & \multirow{2}{*}{ q } \\
\hline & $x^{2}$ & $p$ & $x^{2}$ & $p$ & $t$ & $p$ & $t$ & $p$ & $t$ & $p$ & $t$ & $p$ & & \\
\hline $\begin{array}{l}\text { P. inflatum } \\
\text { vs. control }\end{array}$ & 0 & 1 & 0.23 & 0.63 & 2.56 & $0.02 *$ & -0.11 & 0.91 & -1.9 & 0.07 & -0.01 & 0.1 & 38 & 21 \\
\hline \multicolumn{15}{|c|}{ Fungus present/Aphids present } \\
\hline $\begin{array}{l}\text { C. globosum } \\
\text { vs. control }\end{array}$ & 0.53 & 0.47 & 2.27 & 0.13 & -0.79 & 0.43 & -1.13 & 0.28 & -1.15 & 0.26 & 1.35 & 0.20 & 8 & 11 \\
\hline $\begin{array}{l}\text { P. inflatum } \\
\text { vs. control }\end{array}$ & 0 & 1 & 2.08 & 0.15 & -1.07 & 0.29 & -0.97 & 0.35 & -1.01 & 0.32 & 1.17 & 0.25 & 8 & 12 \\
\hline
\end{tabular}

A Fungus absent
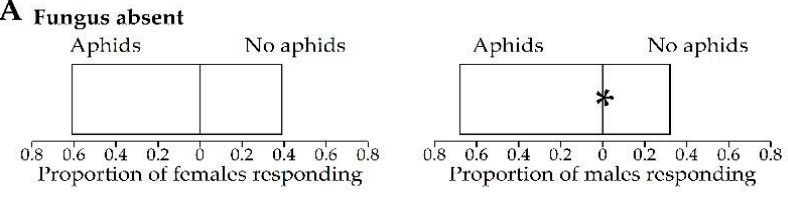

B C. globosum
Aphids
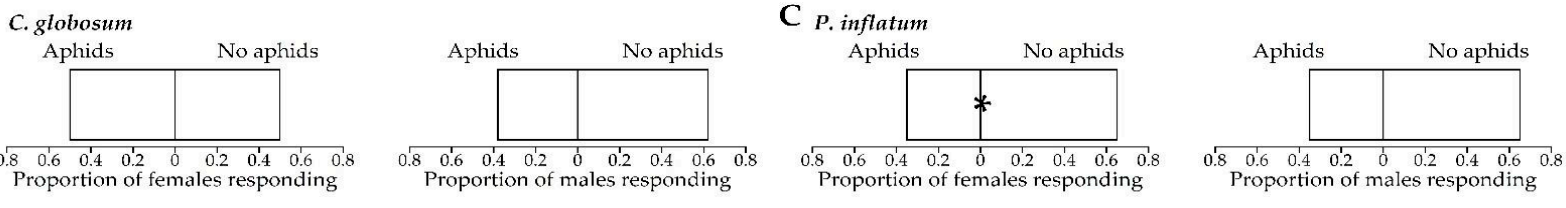

D Fungus present/Aphids absent

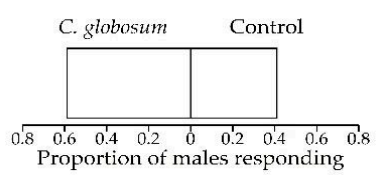

E Fungus present/Aphids absent
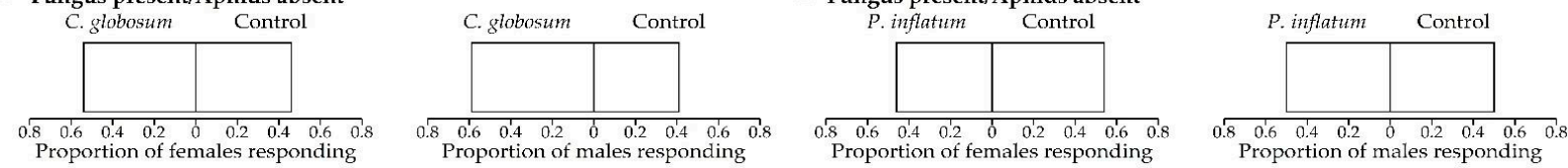

F Fungus present/Aphids present
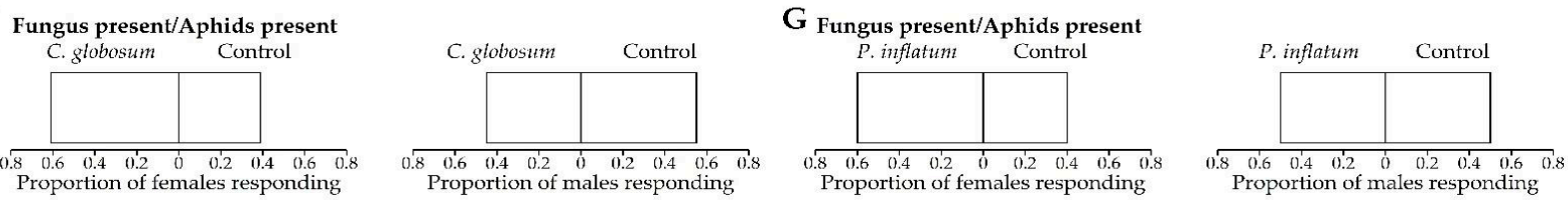

Figure 2. Proportion of Hippodamia convergens females and males responding to untreated control and fungal-treated (Chaetomium globosum and Phialemonium inflatum) cotton plants in a dual-choice Y-tube olfactometer. (A-C) Untreated plants, C. globosum, and P. inflatum treated plants with aphids vs. no aphids, respectively. (D,E) Fungal-treated plants vs. untreated plants, both without aphids. $(\mathrm{F}, \mathrm{G})$ Fungal-treated plants vs. untreated plants, both with aphids. Each individual had $300 \mathrm{~s}$ (five minutes) to make a choice from a total of $600 \mathrm{~s}$, and the beetles that did not respond were not included in the analysis. * $p<0.05$ (Pearson's chi-squared test).

\subsection{Latency to First-Choice}

For the H. convergens females, no significant differences were found in the latency to their first choice among any treatment pairs (Table 1, Figure 3). However, the males exhibited a significant difference in the absence of aphids in cotton plants treated with $P$. inflatum, taking more time to choose the stimuli emitted by the fungal-treated plants relative to untreated control plants. No other significant differences in latency to the first choice were observed in any other treatment comparisons (Table 1, Figure 3).

\subsection{Residence Time}

In the absence of any fungal treatments, $H$. convergens females spent more time in association with the stimuli emitted by aphid-infested plants, whereas the response of 
males was not significantly different. Fungal treatments had no effect on the residence time of the insects in response to stimuli from aphid-infested versus non-infested plants, nor were there any differences between fungal-treated and untreated plants, regardless of whether aphids were present or absent (Table 1, Figure 4).

A Fungus absent

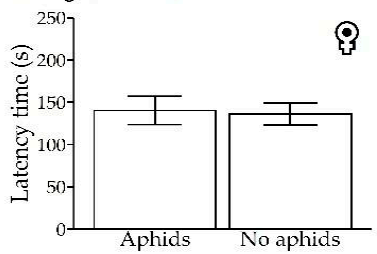

B

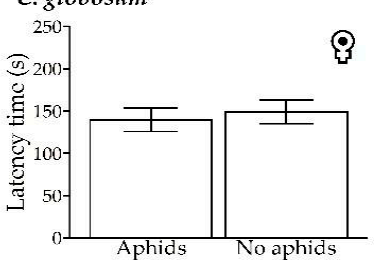

D Fungus present/Aphids absent

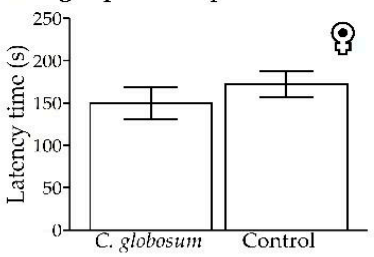

F Fungus present/Aphids present

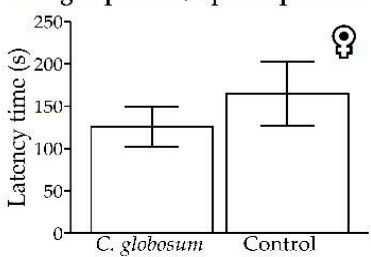

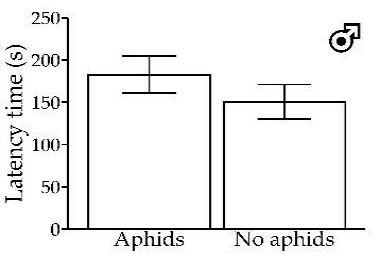

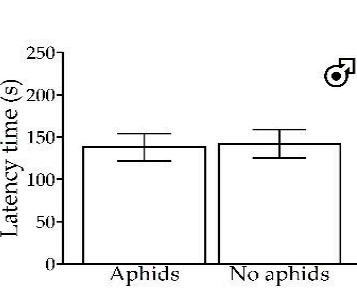

C P. inflatum
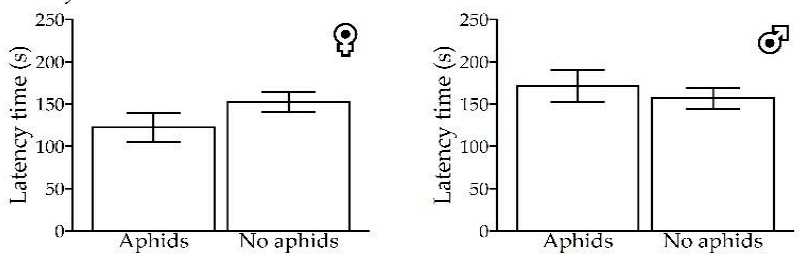

$\mathbf{E}$
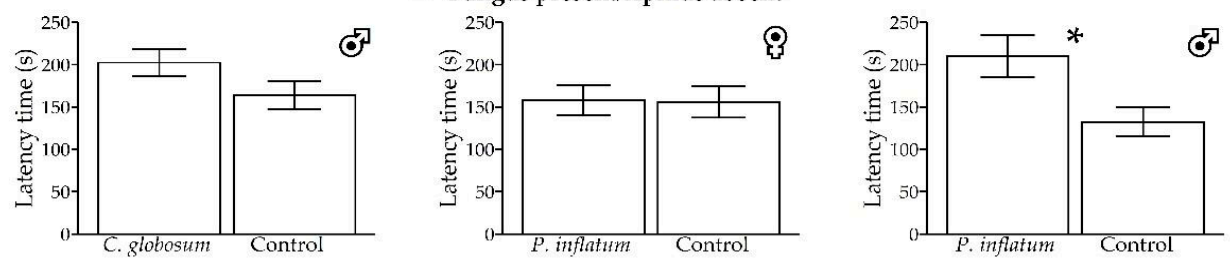

G Fungus present/Aphids present

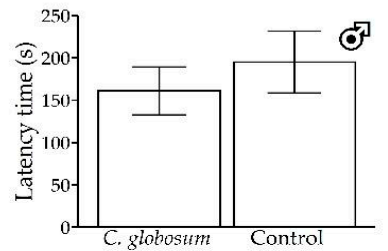

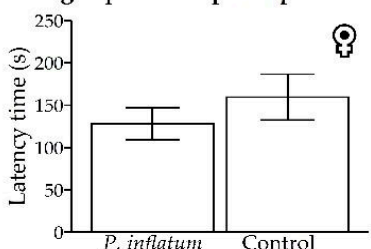

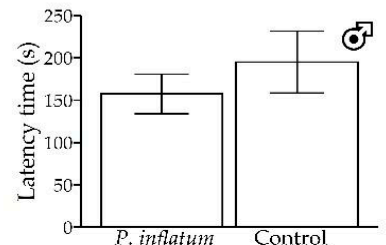

Figure 3. Means $( \pm \mathrm{SE})$ of Hippodamia convergens female and male latency (seconds) to make a choice between olfactory stimuli emitted from untreated control and fungal-treated (Chaetomium globosum and Phialemonium inflatum) cotton plants in a dual-choice Y-tube olfactometer. (A-C) Untreated plants, C. globosum, and P. inflatum treated plants with aphids vs. no aphids, respectively. (D,E) Fungal-treated plants vs. untreated plants, both without aphids. $(F, G)$ Fungal-treated plants vs. untreated plants, both with aphids. Each individual had $300 \mathrm{~s}$ (five minutes) to make a choice from a total of $600 \mathrm{~s}$, and the beetles that did not respond were not included in the analysis. ${ }^{*} p<0.05$ (Welch's two-sample $t$-test). 
A Fungus absent

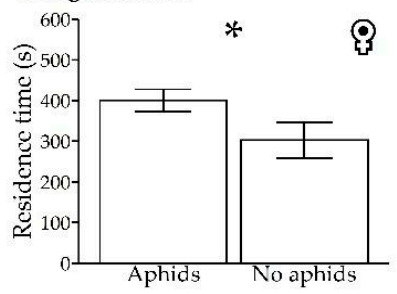

B

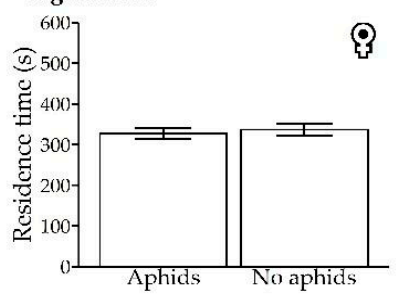

D

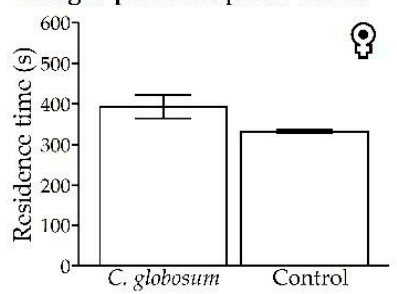

F

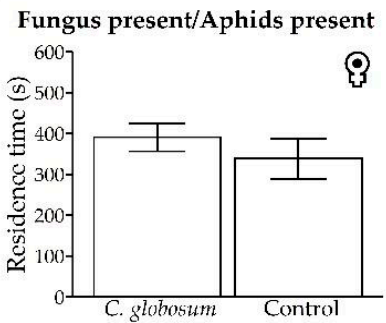

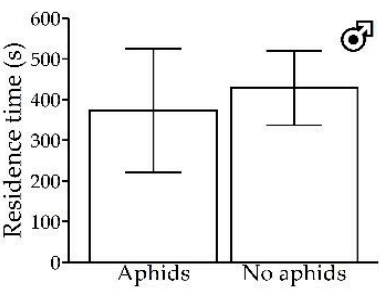

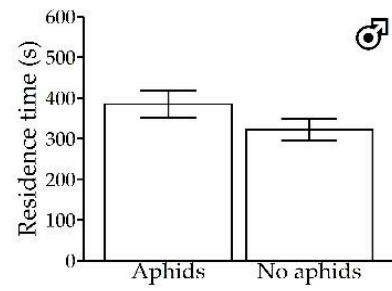

C
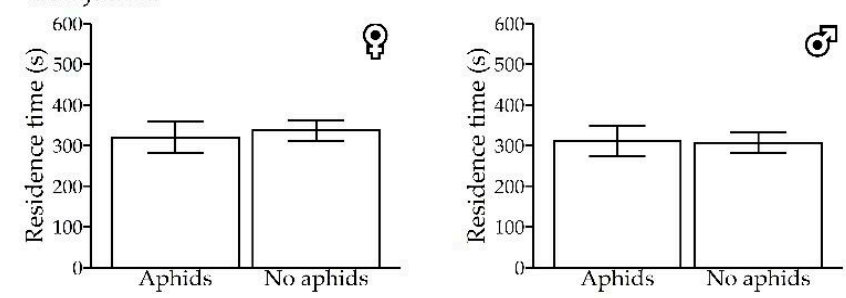

E

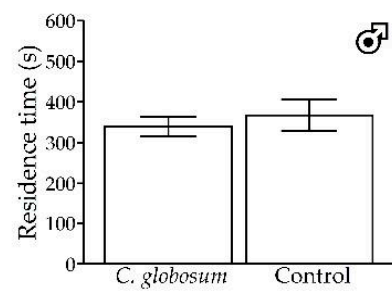

Fungus present/Aphids absent
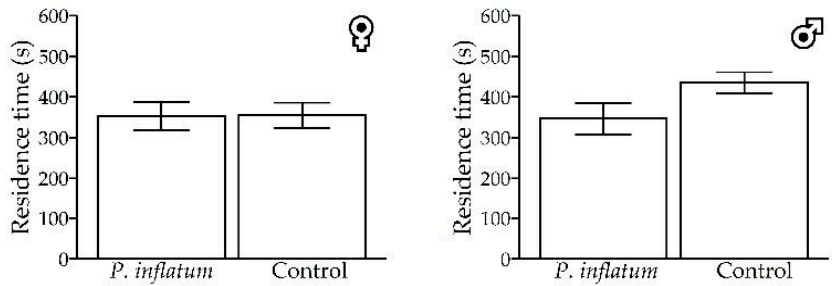

\section{G}
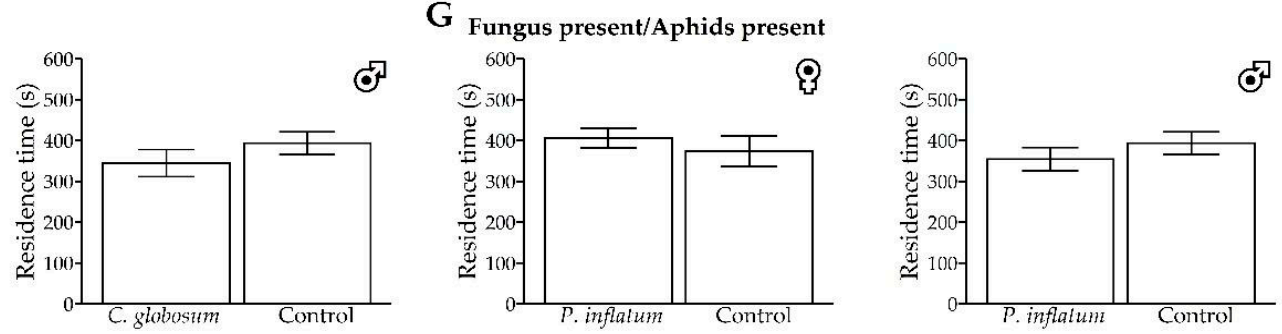

Figure 4. Means $( \pm \mathrm{SE})$ of Hippodamia convergens female and male residence times (seconds) associated with olfactory stimuli emitted from untreated control and fungal-treated (Chaetomium globosum and Phialemonium inflatum) cotton plants in a dual-choice Y-tube olfactometer. (A-C) Untreated plants, C. globosum, and P. inflatum treated plants with aphids vs. no aphids, respectively. (D,E) Fungal-treated plants vs. untreated plants, both without aphids. (F,G) Fungal-treated plants vs. untreated plants, both with aphids. Each individual had $600 \mathrm{~s}$ (10 $\mathrm{min})$ to stay in the Y-tube arm, and the beetles that did not respond were not included in the analysis. ${ }^{*} p<0.05$ (Welch's two-sample $t$-test).

\section{Discussion}

Commonly, aphid-damaged plants are more attractive to lady beetles than noninfested plants $[66,67]$. Hippodamia convergens have previously been shown to be strongly attracted to the odor emitted by plants infested with aphids [68] and to the aphid alarm pheromone [69]. Other predatory beetle species have shown a similar preference for plants infested with aphids as well, such as Coleomegilla maculata (De Geer) females that significantly preferred fava bean plants infested with pea aphids [55]. Moreover, some piercing-sucking insects, including aphids, induce salicylic acid (SA) signaling mediated by feeding, triggering systemic acquired resistance (SAR) in the plant. SAR is primarily thought of as a defense against plant pathogens and can involve plant volatiles [70-72]. Thus, herbivore-induced plant volatiles (HIPVs) and semiochemicals from aphids are potentially available in the environment as olfactory cues for predators and have been 
shown to affect electroantennogram activity, foraging behavior, and attractiveness of prey to coccinellids $[69,73-76]$.

For our first hypothesis, we expected $H$. convergens females and males would prefer olfactory stimuli from aphid-infested cotton plants in the absence of any fungal treatments. We partially supported this hypothesis because only the males showed a clear first choice for aphid-infested plants. The females did not exhibit a first-choice preference in these trials. We expected that both males and females would have lower latency times and higher residence times associated with stimuli from aphid-infested plants in the absence of fungal treatments. However, we did not find a significant difference in latency for either males or females. For residence time, the females spent more time associated with stimuli emitted by aphid-infested plants, but there was no effect on male residence time.

$H$. convergens is a generalist predator, but aphids are its primary food source, and the presence of cotton aphids can increase convergent lady beetle feeding and egg viability $[37,66]$. Thus, we expected that both males and females would have a higher residence time associated with stimuli from aphid-infested plants, but only females showed this pattern in untreated control plants. Coccinella septempunctata (Coleoptera: Coccinellidae) females showed a higher attraction to aphid-infested plants [67], which could explain the higher residence time for females. Elliott, Kieckhefer, and Phoofolo [68] found that the high density of aphids influenced the foraging behavior of the convergent lady beetle with increased residence time in both females and males. The possible explanation for this attractiveness was the influence of chemicals (e.g., volatile sesquiterpenes and alkaloids) on prey and habitat location [69,70]. Both alarm and sexual pheromones of aphids act as attractants for the Asian lady beetle Harmonia axyridis (Pallas) (Coleoptera: Coccinellidae), indicating that these components influence the beetles' behavioral responses [71]. Thus, the preference for aphid-infested plants could be related to the difference in the volatile blends from damaged plants.

For the second hypothesis, we predicted that the fungal treatment of cotton plants would affect the beetles' behavioral responses. The only two significant behavioral responses to fungal treatments observed in these assays involved P. inflatum-treated plants. First, females initially chose stimuli from $P$. inflatum treated plants that were not infested with aphids over those that were infested. Secondly, in the absence of any aphids, males took longer to respond to stimuli from P. inflatum-treated versus untreated control plants. For the first choice, neither females nor males exhibited a preference for stimuli from untreated control cotton plants versus those treated with either C. globosum or P. inflatum regardless of whether aphids were present or absent. We also did not find any significant differences in the residence times of either males or females in the presence or absence of aphids with fungal treatments.

We initially predicted the lady beetles would prefer fungal-treated plants if the VOCs emitted by these plants acted as a cue for host finding that increased plant attractiveness to natural enemies [72]. Plant-associated fungi have previously been shown to cause plants to emit different volatile organic compounds (VOCs) profiles, that by attracting natural enemies, can indirectly act as a plant defense mechanism [73-76]. Other predators, such as Chrysoperla carnea (Stephens) (Neuroptera: Chrysopidae), preferred feeding on cotton aphids when plants had been treated with fungi [76]. One possibility for the observation of males taking more time to respond to stimuli from fungal-treated plants in the absence of aphids is that the stimuli from the fungal-treated plants repelled them. The well-known fungus-plant complex Neotyphodium lolii and Lolium perenne showed negative effects on the aphidophagous C. septempunctata fed on cereal aphids, extending larval development, reducing survival and adult fecundity, and reducing reproductive performance [34] that could lead to a repellency behavior in the presence of fungal-treated plants. In the study conducted with the Neotyphodium-Arizona fescue complex and the bird cherry-oat aphids, C. septempunctata avoided feeding on aphids from plant hybrids with endophyte, showing a preference for other treatments [36]. However, the lady beetles in our experiment had no prior experience with aphids fed on 
fungal-treated plants, so this seems unlikely as an explanation for the increased latency of males to respond to fungal-treated plants that we observed.

The lady beetle females tended to first select stimuli from P. inflatum-treated plants without aphids over stimuli from aphid-infested plants treated with the same fungus. Although we do not know the mechanism underlying this response in our experiments, some herbivores can use secondary metabolites resulting from microbe-plant associations to defend themselves against natural enemies [77,78], making them avoid these plants. In parasitoids, some fungal endophytes can alter the plant alkaloids produced, affecting herbivore susceptibility to natural enemies [79]. Some secondary parasitoids can be negatively influenced by endophytes reducing their lifespan, with experienced females learning to avoid hosts arising from the endophyte-aphid-primary parasitoid interaction [80].

If the fungi played a major role in natural enemy attraction, we would have expected more robust behavioral responses in $H$. convergens towards stimuli from fungal-treated plants, but we did not observe any strong evidence for this in our results. The only observed response to fungal treatment that might have implications for biological control was when plants were treated with $P$. inflatum, and females first preferred stimuli from plants without aphids over those that were infested. If this same response occurred under field conditions, we might expect some reduced lady beetle predation of aphids on P. inflatum-treated plants. However, this same strain of fungi has previously been shown to reduce aphid population growth on cotton when applied in the same manner (5). Thus, although the potential exists for a negative trade-off of P. inflatum treatment in terms of predation, its impact on population dynamics in the field would be expected to be moderated by the direct negative effects of the same fungal treatment on aphid reproduction. Notably, the same potential for a negative trade-off was not suggested in any of the trials involving C. globosum treatment, highlighting the taxonomic specificity in effects on the next trophic level, and the need for more studies investigating the ecological consequences of fungal treatments as an aphid control strategy in the field.

To the best of our knowledge, this is the first study assessing the effects of plantassociated fungi on the behavioral responses of convergent lady beetles. Despite the relatively minor effects observed across the experiments, we did observe some H. convergens responses associated with both aphid infestation and fungal treatments of cotton plants. However, it is critical to acknowledge that this laboratory study is a vast simplification of the complex stimuli and their interactions that would occur in the field. For future work, these effects should be assessed under field conditions to determine whether the attractiveness patterns observed here are different at the spatial scales found in agricultural ecosystems. Moreover, the responses of different species of lady beetles and other predators should be investigated to better understand whether the patterns we observed apply to predators in general or are specific responses of $H$. convergens. Expanding our understanding of natural enemies' responses to cotton treated with plant-associated fungi will improve our ability to utilize fungal treatments as part of IPM strategies.

Author Contributions: Conceptualization, G.A.S.; formal analysis, J.C.S.d.C.; investigation, J.C.S.d.C. and M.H.S.; resources, G.A.S.; writing-original draft preparation, J.C.S.d.C.; writing-review and editing, G.A.S. and M.H.S.; funding acquisition, G.A.S. and J.C.S.d.C. All authors have read and agreed to the published version of the manuscript.

Funding: This research was funded by Coordenação de Aperfeiçoamento de Pessoal de Nível Superior, grant number 88881.129014/2016-01, and the Charles R. Parencia Endowment to the Department of Entomology at Texas A\&M University.

Data Availability Statement: The data presented in this study are available on request from the corresponding author.

Acknowledgments: We thank Cesar Valencia, Zoey Kramer, and Cody Gale for their valuable assistance in the laboratory, and Ashley Tessnow for helpful comments on the manuscript. Charlie Cook of All-Tex Seeds kindly provided cotton seeds for these experiments. 
Conflicts of Interest: The authors declare no conflict of interest. The funders had no role in the design of the study; in the collection, analyses, or interpretation of data; in the writing of the manuscript, or in the decision to publish the results.

\section{References}

1. Hawkes, C.V.; Connor, E.W. Translating Phytobiomes from Theory to Practice: Ecological and Evolutionary Considerations. Phytobiomes J. 2017, 1, 57-69. [CrossRef]

2. Leach, J.E.; Triplett, L.R.; Argueso, C.T.; Trivedi, P. Communication in the Phytobiome. Cell 2017, 169, 587-596. [CrossRef]

3. Gao, F.K.; Dai, C.C.; Liu, X.Z. Mechanisms of fungal endophytes in plant protection against pathogens. Afr. J. Microbiol. Res. 2010, 4, 1346-1351.

4. Porras-Alfaro, A.; Bayman, P. Hidden Fungi, Emergent Properties: Endophytes and Microbiomes. Annu. Rev. Phytopathol. 2011, 49, 291-315. [CrossRef] [PubMed]

5. $\quad$ Lopez, D.C.; Zhu-Salzman, K.; Ek-Ramos, M.J.; Sword, G.A. The Entomopathogenic Fungal Endophytes Purpureocillium lilacinum (Formerly Paecilomyces lilacinus) and Beauveria bassiana Negatively Affect Cotton Aphid Reproduction under Both Greenhouse and Field Conditions. PLoS ONE 2014, 9, e103891. [CrossRef]

6. Hubbard, M.; Germida, J.J.; Vujanovic, V. Fungal endophytes enhance wheat heat and drought tolerance in terms of grain yield and second-generation seed viability. J. Appl. Microbiol. 2014, 116, 109-122. [CrossRef] [PubMed]

7. Lopez, D.C.; Sword, G.A. The endophytic fungal entomopathogens Beauveria bassiana and Purpureocillium lilacinum enhance the growth of cultivated cotton (Gossypium hirsutum) and negatively affect survival of the cotton bollworm (Helicoverpa zea). Biol. Control 2015, 89, 53-60. [CrossRef]

8. Zhou, W.; Starr, J.L.; Krumm, J.L.; Sword, G.A. The fungal endophyte Chaetomium globosum negatively affects both above- and belowground herbivores in cotton. FEMS Microbiol. Ecol. 2016, 92, fiw158. [CrossRef]

9. Sword, G.A.; Tessnow, A.; Ek-Ramos, M.J. Endophytic fungi alter sucking bug responses to cotton reproductive structures. Insect Sci. 2017, 24, 1003-1014. [CrossRef]

10. Bamisile, B.S.; Dash, C.K.; Akutse, K.S.; Keppanan, R.; Wang, L. Fungal Endophytes: Beyond Herbivore Management Front. Microbiol. 2018, 9, 544. [CrossRef]

11. Zhou, W.Q.; Wheeler, T.A.; Starr, J.L.; Valencia, C.U.; Sword, G.A. A fungal endophyte defensive symbiosis affects plant-nematode interactions in cotton. Plant Soil 2016, 422, 251-266. [CrossRef]

12. Dini-Andreote, F. Endophytes: The second layer of plant defense. Trends Plant Sci. 2020, 25, 4. [CrossRef] [PubMed]

13. Zhou, W.; Verma, V.C.; Wheeler, T.A.; Woodward, J.E.; Starr, J.L.; Sword, G.A. Tapping into the Cotton Fungal Phytobiome for Novel Nematode Biological Control Tools. Phytobiomes J. 2020, 4, 19-26. [CrossRef]

14. Ownley, B.H.; Griffin, M.R.; Klingeman, W.E.; Gwinn, K.D.; Moulton, J.K.; Pereira, R. Beauveria bassiana: Endophytic colonization and plant disease control. J. Invertebr. Pathol. 2008, 98, 267-270. [CrossRef]

15. Shikano, I.; Rosa, C.; Tan, C.-W.; Felton, G.W. Tritrophic Interactions: Microbe-Mediated Plant Effects on Insect Herbivores Annu. Rev. Phytopathol. 2017, 55, 313-331. [CrossRef] [PubMed]

16. Ahmad, I.; Jiménez-Gasco, M.D.M.; Luthe, D.S.; Shakeel, S.N.; Barbercheck, M.E. Endophytic Metarhizium robertsii promotes maize growth, suppresses insect growth, and alters plant defense gene expression. Biol. Control 2020, 144, 104167. [CrossRef]

17. Newcombe, G.; Shipunov, A.; Eigenbrode, S.D.; Raghavendra, A.K.; Ding, H.; Anderson, C.L.; Menjivar, R.; Crawford, M.; Schwarzländer, M. Endophytes influence protection and growth of an invasive plant. Commun. Integr. Biol. 2009, 2, 29-31. [CrossRef]

18. Davis, T.S.; Crippen, T.L.; Hofstetter, R.W.; Tomberlin, J.K. Microbial Volatile Emissions as Insect Semiochemicals. J. Chem. Ecol. 2013, 39, 840-859. [CrossRef]

19. Wani, Z.A.; Ashraf, N.; Mohiuddin, T.; Riyaz-Ul-Hassan, S. Plant-endophyte symbiosis, an ecological perspective. Appl. Microbiol. Biotechnol. 2015, 99, 2955-2965. [CrossRef]

20. Daisy, B.H.; Strobel, G.A.; Castillo, U.; Ezra, D.; Sears, J.; Weaver, D.K.; Runyon, J.B. Naphthalene, an insect repellent, is produced by Muscodor vitigenus, a novel endophytic fungus. Microbiol. 2002, 148, 3737-3741. [CrossRef]

21. Jallow, M.F.A.; Dugassa-Gobena, D.; Vidal, S. Influence of an endophytic fungus on host plant selection by a polyphagous moth via volatile spectrum changes. Arthropod-Plant Interact. 2008, 2, 53-62. [CrossRef]

22. Rostás, M.; Cripps, M.G.; Silcock, P. Aboveground endophyte affects root volatile emission and host plant selection of a belowground insect. Oecologia 2014, 177, 487-497. [CrossRef] [PubMed]

23. McCormick, A.C.; Unsicker, S.B.; Gershenzon, J. The specificity of herbivore-induced plant volatiles in attracting herbivore enemies. Trends Plant Sci. 2012, 17, 303-310. [CrossRef] [PubMed]

24. Xiao, Y.; Wang, Q.; Erb, M.; Turlings, T.C.J.; Ge, L.; Hu, L.; Li, J.; Han, X.; Zhang, T.; Lu, J.; et al. Specific herbivore-induced volatiles defend plants and determine insect community composition in the field. Ecol. Lett. 2012, 15, 1130-1139. [CrossRef]

25. Kersting, U.; Satar, S.; Uygun, N. Effect of temperature on development rate and fecundity of apterous Aphis gossypii Glover (Hom., Aphididae) reared on Gossypium hirsutum L. J. Appl. Entomol. 1999, 123, 23-27. [CrossRef] 
26. Lu, Y.; Wu, K.; Jiang, Y.; Guo, Y.; Desneux, N. Widespread adoption of Bt cotton and insecticide decrease promotes biocontrol services. Nature 2012, 487, 362-365. [CrossRef]

27. Gurulingappa, P.; Sword, G.A.; Murdoch, G.; McGee, P.A. Colonization of crop plants by fungal entomopathogens and their effects on two insect pests when in planta. Biol. Control 2010, 55, 34-41. [CrossRef]

28. González-Mas, N.; Quesada-Moraga, E.; Plaza, M.; Fereres, A.; Moreno, A. Changes in feeding behaviour are not related to the reduction in the transmission rate of plant viruses by Aphis gossypii (Homoptera: Aphididae) to melon plants colonized by Beauveria bassiana (Ascomycota: Hypocreales). Biol. Control 2019, 130, 95-103. [CrossRef]

29. Hodek, I.; Evans, E.W. Food Relationships. In Ecology and Behaviour of the Ladybird Beetles (Coccinellidae); Hodek, I., Emden, H.F.v., Honěk, A., Eds.; John Wiley \& Sons: Hoboken, NJ, USA, 2012; pp. 141-274. [CrossRef]

30. Koch, R.L.; Costamagna, A.C. Reaping benefits from an invasive species: Role of Harmonia axyridis in natural biological control of Aphis glycines in North America. BioControl 2017, 62, 331-340. [CrossRef]

31. Riddick, E.W. Spotlight on the positive effects of the ladybird Harmonia axyridis on agriculture. Entomophaga 2017, 62, 319-330. [CrossRef]

32. Flint, M.L.; Dreistadt, S.H. Interactions among convergent lady beetle (Hippodamia convergens) releases, aphid populations, and rose cultivar. Biol. Control 2005, 34, 38-46. [CrossRef]

33. Bjørnson, S. Natural enemies of the convergent lady beetle, Hippodamia convergens Guérin-Méneville: Their inadvertent importation and potential significance for augmentative biological control. Biol. Control 2008, 44, 305-311. [CrossRef]

34. De Sassi, C.; Müller, C.B.; Krauss, J. Fungal plant endosymbionts alter life history and reproductive success of aphid predators. Proc. R. Soc. B Biol. Sci. 2006, 273, 1301-1306. [CrossRef] [PubMed]

35. Fuchs, B.; Krischke, M.; Mueller, M.J.; Krauss, J. Peramine and Lolitrem B from Endophyte-Grass Associations Cascade Up the Food Chain. J. Chem. Ecol. 2013, 39, 1385-1389. [CrossRef] [PubMed]

36. Saari, S.; Richter, S.; Robbins, M.; Faeth, S.H. Bottom-up regulates top-down: The effects of hybridization of grass endophytes on an aphid herbivore and its generalist predator. Oikos 2014, 123, 545-552. [CrossRef]

37. Prasifka, J.R.; Heinz, K.M.; Winemiller, K.O. Crop colonisation, feeding, and reproduction by the predatory beetle, Hippodamia convergens, as indicated by stable carbon isotope analysis. Ecol. Entomol. 2004, 29, 226-233. [CrossRef]

38. Bastola, A.; Parajulee, M.N.; Porter, R.P.; Shrestha, R.B.; Carroll, S.C.; Chen, F.-J. Intercrop movement of convergent lady beetle, Hippodamia convergens (Coleoptera: Coccinellidae), between adjacent cotton and alfalfa. Insect Sci. 2015, 23, 145-156. [CrossRef]

39. Miranda, J. Manejo integrado de pragas do algodoeiro no cerrado brasileiro. In Circular Técnica (INFOTECA-E); Embrapa Algodão: Campina Grande, Brazil, 2010.

40. Jaber, L.R.; Araj, S.-E. Interactions among endophytic fungal entomopathogens (Ascomycota: Hypocreales), the green peach aphid Myzus persicae Sulzer (Homoptera: Aphididae), and the aphid endoparasitoid Aphidius colemani Viereck (Hymenoptera: Braconidae). Biol. Control 2018, 116, 53-61. [CrossRef]

41. Ek-Ramos, M.J.; Zhou, W.; Valencia, C.U.; Antwi, J.B.; Kalns, L.; Morgan, G.D.; Kerns, D.L.; Sword, G.A.; Ek-Ramos, M.J. Spatial and Temporal Variation in Fungal Endophyte Communities Isolated from Cultivated Cotton (Gossypium hirsutum). PLoS ONE 2013, 8, e66049. [CrossRef]

42. Posada, F.; Aime, M.C.; Peterson, S.W.; Rehner, S.A.; Vega, F.E. Inoculation of coffee plants with the fungal entomopathogen Beauveria bassiana (Ascomycota: Hypocreales). Mycol. Res. 2007, 111, 748-757. [CrossRef]

43. Rodrigues, A.R.S.; Ruberson, J.R.; Torres, J.B.; Siqueira, H.Á.A.; Scott, J.G. Pyrethroid resistance and its inheritance in a field population of Hippodamia convergens (Guérin-Méneville) (Coleoptera: Coccinellidae). Pestic. Biochem. Physiol. 2013, 105, 135-143. [CrossRef]

44. Barbosa, P.R.; Michaud, J.P.; Rodrigues, A.R.; Torres, J.B. Dual resistance to lambda-cyhalothrin and dicrotophos in Hippodamia convergens (Coleoptera: Coccinellidae). Chemosphere 2016, 159, 1-9. [CrossRef] [PubMed]

45. Michaud, J.; Qureshi, J.A. Induction of reproductive diapause in Hippodamia convergens (Coleoptera: Coccinellidae) hinges on prey quality and availability. Eur. J. Entomol. 2005, 102, 483-487. [CrossRef]

46. Michaud, J.; Qureshi, J.A. Reproductive diapause in Hippodamia convergens (Coleoptera: Coccinellidae) and its life history consequences. Biol. Control 2006, 39, 193-200. [CrossRef]

47. Schaller, M.; Nentwig, W. Olfactory orientation of the seven-spot ladybird beetle, Coccinella septempunctata (Coleoptera: Coccinellidae): Attraction of adults to plants and conspecific females. Eur. J. Entomol. 2000, 97, 155-160. [CrossRef]

48. Adedipe, F.; Park, Y.-L. Visual and olfactory preference of Harmonia axyridis (Coleoptera: Coccinellidae) adults to various companion plants. J. Asia-Pac. Entomol. 2010, 13, 319-323. [CrossRef]

49. Xiu, C.-L.; Xu, B.; Pan, H.-S.; Zhang, W.; Yang, Y.-Z.; Lu, Y.-H. Volatiles from Sophora japonica flowers attract Harmonia axyridis adults (Coleoptera: Coccinellidae). J. Integr. Agric. 2019, 18, 873-883. [CrossRef]

50. Borges, M.; Millar, J.G.; Laumann, R.A.; Blassioli-Moraes, M.C.B. A Male-produced Sex Pheromone from the Neotropical Redbanded Stink Bug, Piezodorus guildinii (W.). J. Chem. Ecol. 2007, 33, 1235-1248. [CrossRef]

51. Magalhães, D.M.; Borges, M.; Laumann, R.A.; Sujii, E.R.; Mayon, P.; Caulfield, J.C.; Midega, C.A.O.; Khan, Z.R.; Pickett, J.A.; Birkett, M.; et al. Semiochemicals from Herbivory Induced Cotton Plants Enhance the Foraging Behavior of the Cotton Boll Weevil, Anthonomus grandis. J. Chem. Ecol. 2012, 38, 1528-1538. [CrossRef] 
52. Magalhães, D.M.; Borges, M.; Laumann, R.A.; Moraes, M.C.B. Influence of multiple- and single-species infestations on herbivoreinduced cotton volatiles and Anthonomus grandis behaviour. J. Pest Sci. 2018, 91, 1019-1032. [CrossRef]

53. Magalhães, D.M.; Borges, M.; Laumann, R.A.; Woodcock, C.M.; Withall, D.M.; Pickett, J.A.; Birkett, M.A.; Blassioli-Moraes, M.C. Identification of Volatile Compounds Involved in Host Location by Anthonomus grandis (Coleoptera: Curculionidae). Front. Ecol. Evol. 2018, 6, 98. [CrossRef]

54. Bahlai, C.A.; Welsman, J.A.; MacLeod, E.C.; Schaafsma, A.W.; Hallett, R.H.; Sears, M.K. Role of Visual and Olfactory Cues from Agricultural Hedgerows in the Orientation Behavior of Multicolored Asian Lady Beetle (Coleoptera: Coccinellidae) Environ. Entomol. 2008, 37, 973-979. [CrossRef] [PubMed]

55. Choate, B.A.; Lundgren, J.G. Why eat extrafloral nectar? Understanding food selection by Coleomegilla maculata (Coleoptera: Coccinellidae). Entomophaga 2013, 58, 359-367. [CrossRef]

56. Duffy, A.G.; Hughes, G.P.; Ginzel, M.D.; Richmond, U.S. Volatile and Contact Chemical Cues Associated with Host and Mate Recognition Behavior of Sphenophorus venatus and Sphenophorus parvulus (Coleoptera: Dryophthoridae). J. Chem. Ecol. 2018, 44, 556-564. [CrossRef] [PubMed]

57. Rim, H.; Uefune, M.; Ozawa, R.; Takabayashi, J. An omnivorous arthropod, Nesidiocoris tenuis, induces gender-specific plant volatiles to which conspecific males and females respond differently. Arthropod-Plant Interact. 2018, 12, 495-503. [CrossRef]

58. Barloggio, G.; Tamm, L.; Nagel, P.; Luka, H. Selective flowers to attract and enhance Telenomus laeviceps (Hymenoptera: Scelionidae): A released biocontrol agent of Mamestra brassicae (Lepidoptera: Noctuidae). Bull. Entomol. Res. 2019, 109, 160-168. [CrossRef]

59. Xiu, C.L.; Dai, W.J.; Pan, H.S.; Zhang, W.; Luo, S.P.; Wyckhuys, K.A.G.; Yang, Y.Z.; Lu, Y.H. Herbivore-induced plant volatiles enhance field-level parasitism of the mirid bug Apolygus lucorum. Biol. Control 2019, 135, 41-47. [CrossRef]

60. Martin, P.; Bateson, P.P.G. Measuring Behaviour: An Introductory Guide, 3rd ed.; Cambridge University Press: Cambridge, UK, 2007. [CrossRef]

61. R Core Team. R: A Language and Environment for Statistical Computing; R Foundation for Statistical Computing: Vienna, Austria, 2020

62. Sokame, B.M.; Ntiri, E.S.; Ahuya, P.; Torto, B.; Le Ru, B.P.; Kilalo, D.C.; Juma, G.; Calatayud, P.-A. Caterpillar-induced plant volatiles attract conspecific and heterospecific adults for oviposition within a community of lepidopteran stemborers on maize plant. Chemoecology 2019, 29, 89-101. [CrossRef]

63. Sarkar, N.; Mukherjee, A.; Barik, A. Attraction of Epilachna dodecastigma (Coleoptera: Coccinellidae) to Momordica charantia (Cucurbitaceae) leaf volatiles. Can. Èntomol. 2015, 147, 169-180. [CrossRef]

64. Michereff, M.F.F.; Magalhães, D.M.; Hassemer, M.J.; Laumann, R.A.; Zhou, J.-J.; Ribeiro, P.E.D.A.; Viana, P.A.; Guimarães, P.E.D.O.; Schimmelpfeng, P.H.C.; Borges, M.; et al. Variability in herbivore-induced defence signalling across different maize genotypes impacts significantly on natural enemy foraging behaviour. J. Pest Sci. 2018, 92, 723-736. [CrossRef]

65. Wickham, H. ggplot2: Elegant Graphics for Data Analysis; Springer: New York, NY, USA, 2016.

66. Obrycki, J.J.; Harwood, J.D.; Kring, T.J.; O’Neil, R.J. Aphidophagy by Coccinellidae: Application of biological control in agroecosystems. Biol. Control 2009, 51, 244-254. [CrossRef]

67. Norkute, M.; Olsson, U.; Ninkovic, V. Aphids-induced plant volatiles affect diel foraging behavior of a ladybird beetle Coccinella septempunctata. Insect Sci. 2020, 27, 1266-1275. [CrossRef] [PubMed]

68. Elliott, N.C.; Kieckhefer, R.W.; Phoofolo, M.W. Foraging by Hippodamia convergens for Cereal Aphids on Wheat Plants in the Laboratory. Southwest. Entomol. 2011, 36, 1-10. [CrossRef]

69. Verheggen, F.J.; Fagel, Q.; Heuskin, S.; Lognay, G.; Francis, F.; Haubruge, E. Electrophysiological and Behavioral Responses of the Multicolored Asian Lady Beetle, Harmonia axyridis Pallas, to Sesquiterpene Semiochemicals. J. Chem. Ecol. 2007, 33, $2148-2155$. [CrossRef]

70. Sloggett, J.J.; Magro, A.; Verheggen, F.J.; Hemptinne, J.-L.; Hutchison, W.D.; Riddick, E.W. The chemical ecology of Harmonia axyridis. Entomophaga 2011, 56, 643-661. [CrossRef]

71. Leroy, P.D.; Schillings, T.; Farmakidis, J.; Heuskin, S.; Lognay, G.; Verheggen, F.J.; Brostaux, Y.; Haubruge, E.; Francis, F. Testing semiochemicals from aphid, plant and conspecific: Attraction of Harmonia axyridis. Insect Sci. 2012, 19, 372-382. [CrossRef]

72. Song, G.C.; Ryu, C.-M. Two Volatile Organic Compounds Trigger Plant Self-Defense against a Bacterial Pathogen and a Sucking Insect in Cucumber under Open Field Conditions. Int. J. Mol. Sci. 2013, 14, 9803-9819. [CrossRef]

73. Guerrieri, E.; Lingua, G.; Digilio, M.C.; Massa, N.; Berta, G. Do interactions between plant roots and the rhizosphere affect parasitoid behaviour? Ecol. Entomol. 2004, 29, 753-756. [CrossRef]

74. Schausberger, P.; Peneder, S.; Jürschik, S.; Hoffmann, D. Mycorrhiza changes plant volatiles to attract spider mite enemies. Funct. Ecol. 2012, 26, 441-449. [CrossRef]

75. Fuchs, B.; Krauss, J. Can Epichloë endophytes enhance direct and indirect plant defence? Fungal Ecol. 2019, 38, 98-103. [CrossRef]

76. González-Mas, N.; Cuenca-Medina, M.; Gutiérrez-Sánchez, F.; Quesada-Moraga, E. Bottom-Up effects of endophytic Beauveria bassiana on multitrophic interactions between the cotton aphid, Aphis gossypii, and its natural enemies in melon. J. Pest Sci. 2019, 92, 1271-1281. [CrossRef] 
77. Kunkel, B.A.; Grewal, P.S. Endophyte infection in perennial ryegrass reduces the susceptibility of black cutworm to an entomopathogenic nematode. Entomol. Exp. Appl. 2003, 107, 95-104. [CrossRef]

78. Kunkel, B.A.; Grewal, P.S.; Quigley, M.F. A mechanism of acquired resistance against an entomopathogenic nematode by Agrotis ipsilon feeding on perennial ryegrass harboring a fungal endophyte. Biol. Control 2004, 29, 100-108. [CrossRef]

79. Bultman, T.L.; McNeill, M.R.; Goldson, S.L. Isolate-dependent impacts of fungal endophytes in a multitrophic interaction. Oikos 2003, 102, 491-496. [CrossRef]

80. Härri, A.; Krauss, J.; Müller, C.B. Fungal endosymbionts of plants reduce lifespan of an aphid secondary parasitoid and influence host selection. Proc. R. Soc. Lond. Ser. B Biol. Sci. 2008, 275, 2627-2632. [CrossRef] [PubMed] 